\title{
Chapter 11 \\ Sustainable Development, Climate Change, and Renewable Energy in Rural Central America
}

\section{Debora Ley}

\begin{abstract}
Decentralized renewable energy (DRE) projects have the potential to contribute to climate change mitigation, climate change adaptation, and sustainable development objectives. DRE systems are considered for emissions reduction or poverty alleviation purposes while their role for climate change adaptation has hardly been analysed. In terms of adaptation, DRE provides electricity that can be used both to prepare for and recover from disasters, and to provide additional income and livelihood opportunities, thus reducing dependency on natural resources. For example, DRE can power early warning systems, telecommunication systems, health clinics and potable water systems. Although it might be said that climate change adaptation applications of DRE systems have already been implemented, the vulnerability of these systems towards climate impacts, and the robustness of these systems to climatic impacts are oftentimes not even considered.

The assessment of 15 community-owned renewable energy projects in Guatemala and Nicaragua show that, under certain conditions, renewable energy projects can simultaneously meet the triple objective of sustainable development and climate change mitigation and adaptation. Research also points to specific drivers which can facilitate or hinder projects meeting their own stated objectives and, consequently, the triple objective, and their long-term functioning. These drivers include the specific background of the beneficiary community, the financing and implementing entities and the local governance structures in place.
\end{abstract}

Keywords Renewable energy - Climate change mitigation - Climate change adaptation - Central America $\bullet$ Sustainable development $\bullet$ Rural electrification • Evaluation

\footnotetext{
D. Ley $(\bowtie)$

Environmental Change Institute, School of Geography and the Environment,

University of Oxford, Oxford, UK

e-mail: debbieannley@yahoo.com
} 


\subsection{Introduction}

Renewable energy technologies can provide energy to rural populations to which it is technically or economically infeasible to extend the electricity grid. Electricity can be used for applications ranging from lighting to a wide array of productive uses to energy services supporting health, education, and sanitation. Current research has mainly focused on the impacts and case studies of DRE on poverty alleviation and sustainable development.

Climate change adaptation is necessary due to the adverse impacts of increasingly frequent extreme weather events. The poorest and most vulnerable populations within developing countries suffer the worst effects of extreme weather events, especially populations in which natural resource bases are fundamental for their livelihoods (Adger et al. 2003; Thomas and Twyman 2005). The United Nations Development Programme (UNDP) 2007/2008 Human Development Report (HDR) first emphasized the importance of adaptation integrated with development since 'adaptation is about development for all' (UNDP 2007). Therefore, failure to address adaptation will deter developing countries from growing economically and alleviating poverty (UNDP 2007).

Adaptation literature has focused on specific topics that include crop diversification (Bradshaw et al. 2004; Naylor et al. 2007), insurance (Crichton 2007, Linnerooth-Bayer and Mechler 2006; Mills 2007; Moser et al. 2007; Romilly 2007; Johnson et al. 2007), the ski industry, and flood risk management (Johnson et al. 2007; Tol et al. 2003). However, there is scant literature on the use of renewable energy to increase adaptive capacity. Eriksen and O'Brien (2007) and Venema and Rehman (2007) hypothesize DRE may be one strategy to meet the triple objective, although they don't provide in-depth details on how this will happen.

The role of renewable energy systems to meet climate change mitigation goals has been well documented (CEPAL 2007a,b). Market-based policy instruments have been created to mitigate climate change without sustainable development objectives always being met. For example, ocal, small-scale renewable energy projects, which have a larger development component, haven't been main participants within CDM project portfolios, while they have figured more prominently under Voluntary Carbon Offset (VCO) initiatives. As such, VCO projects include have a greater focus on development objectives than the CDM. Even though rural development projects have been included within the CDM, there is a need to create a clear set of guidelines to effectively incorporate sustainable development objectives into the projects.

The use of DRE is the only cost-effective and environmentally sound option to provide access to electricity to many rural populations. Only recently has energy access been viewed as a necessary, though not sufficient, enabler for development, including the achievement of the Millennium Development Goals (MDGs) and now of the Sustainable Development Goals (SDGs). The lack of basic infrastructure, including energy, has prevented some countries from achieving the MDG's in rural 
areas, while meeting them in the urban sector. As in the case of the MDG's, energy serves as an enabler for the achievement of other goals under the SDG's. Additionally, SDG 7 addresses the energy sector specifically by 'ensuring access to affordable, reliable, sustainable and modern energy for all'. The linkage with climate change comes in SDG 13, which calls to 'take urgent action to combat climate change and its impacts'.

My research examines the relationships between sustainable development, climate change and renewable energy in rural Central America. The main research question I answer is 'Can rural renewable energy projects simultaneously meet the multiple goals of sustainable development, climate change mitigation and climate change adaptation? If so, under what conditions?' and I use three guiding questions:

1. How well are RE projects meeting their goals of sustainable development, climate change mitigation and climate change adaptation?

2. What are the relative roles of local historical background and physical characteristics, type of community governance, and funding source and project implementation process in the success of projects in meeting adaptation, mitigation and development goals?

3. What are the challenges in integrating development and climate change adaptation policies in rural Central America? How might the evolving international climate regime contribute to this integration?

I also look at how the climate change mitigation, climate change adaptation and sustainable development mainstreaming and integration can take place. For this research, and as defined by Sperling, mainstreaming indicates that climate issues are being used for planning and budgeting decision making while integration is used when specific adaptation measures are added to design and implementation strategies (Sperling 2003). That is, mainstreaming includes climate change considerations, that go beyond adaptation, from the outset during project planning.

\subsection{Approach}

I used the political ecology approach to assess the importance of, and relationships between, political economy, social and community structures, local historical backgrounds and the use of natural resources. The approach provides a useful framework for evaluating rural renewable energy projects, focusing on institutions (such as common property resources), markets, local response to development interventions and to the material effects of development on the physical environment (for example, water, soil, and carbon).

Political ecology studies of Latin America are mostly related to the relationship between poverty and environmental degradation: poverty and conservation efforts in protected areas, development, land degradation, wildlife and livelihoods, land use change, land use and food security, shrimp mariculture and fisheries, and 
irrigation and water resources. The energy sector has also been an area of study for political ecology and political economy, including the use of wood fuel, the wind turbine industry and U.S. energy policy; however, other RE systems haven't been analysed. The existence and type of local governance structures, the level of poverty, and population displacement due to civil wars are among the considerations important to the 'surrounding causes, experiences, and management of environmental problems' (Blaikie and Brookfield 1987) that will contribute to the debate around mainstreaming development with climate change mitigation and adaptation.

Key ways that political ecology influences research design are through the attention to material carbon reductions, climate impacts, renewable energy in the structures of markets and policies and their and responses to changes.

Common Property Resources (CPR) were analyzed as an institution under political ecology, since all the development projects evaluated were community owned. I also used the Pressure and Release (PAR) model for the analysis of renewable energy systems meeting climate change adaptation goals.

Research on CPR has covered topics surrounding natural resources and their uses, including aquaculture, trade, forestry, neoliberalism, ecotourism and coastal livelihoods. Energy use, including renewable energy, has also been studied through a CPR approach, mainly focusing on the optimal use of finite sources.

Ostrom designed principles to determine the failure or success of CPR. As part of the research design, I analysed whether the 'design principles for common property resources' identified by Ostrom (2002) also apply to community-owned renewable energy systems (Table 11.1).

CPR appears as a major set of institutions for managing resources. However, agency (actions of individuals) does influence CPR's when the CPR rules are changed by the people/community. Political ecology has had very few studies of renewable energy in relation to climate governance, local communities and the actions of individuals (agency). Figure 11.1 shows the relationship between CPR and PE.

Based on Political Ecology and CPR, I would expect that the success of projects would be explained by:

1. Political and economic structures that secure property rights; access to resources; equitable benefits; communal ownership and local management of the renewable energy system; taking into account the role and impact of local institutions and the influence of government and foreign and international donor agencies.

2. The agency of individuals in a community and project managers who seek the success of a project and work towards it.

3. Constraints and opportunities afforded by the physical environment, historical background, and cultural and religious diversity.

4. Relationship with Ostrom's rules for successful CPR management, and defined rules, sanctions and incentives.

The evaluation for potential for adaptive capacity and adaptation to climate hazards was carried out using the Pressure And Release (PAR) model. The PAR 
11 Sustainable Development, Climate Change, and Renewable Energy in Rural...

Table 11.1 Ostrom's common property resources design principles

1. Resource system characteristics

a. Well-defined boundaries

2. Group characteristics

a. Well-defined boundaries

(1 and 2) Relationship between resource system characteristics and group characteristics

3. Institutional arrangements

a. Locally devised access and management rules

b. Ease in enforcement of rules

c. Graduated sanctions

d. Availability of low-cost adjudication

e. Accountability of monitors and other officials to users

(1 and 3) Relationship between resource system and institutional arrangements

a. Match restrictions on harvests to regeneration of resources

4. External environment
a. Technology
b. State
i. Central governments should not undermine local authority
ii. Nested levels of appropriation, provision, enforcement, governance

Ostrom (2002)

Fig. 11.1 Relationship between the theories of common property resources and political ecology

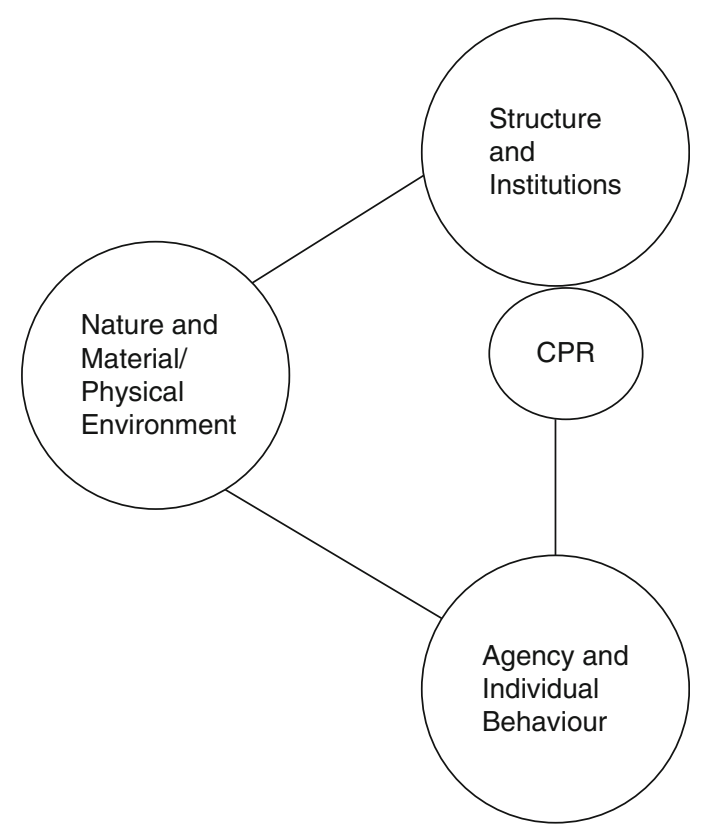




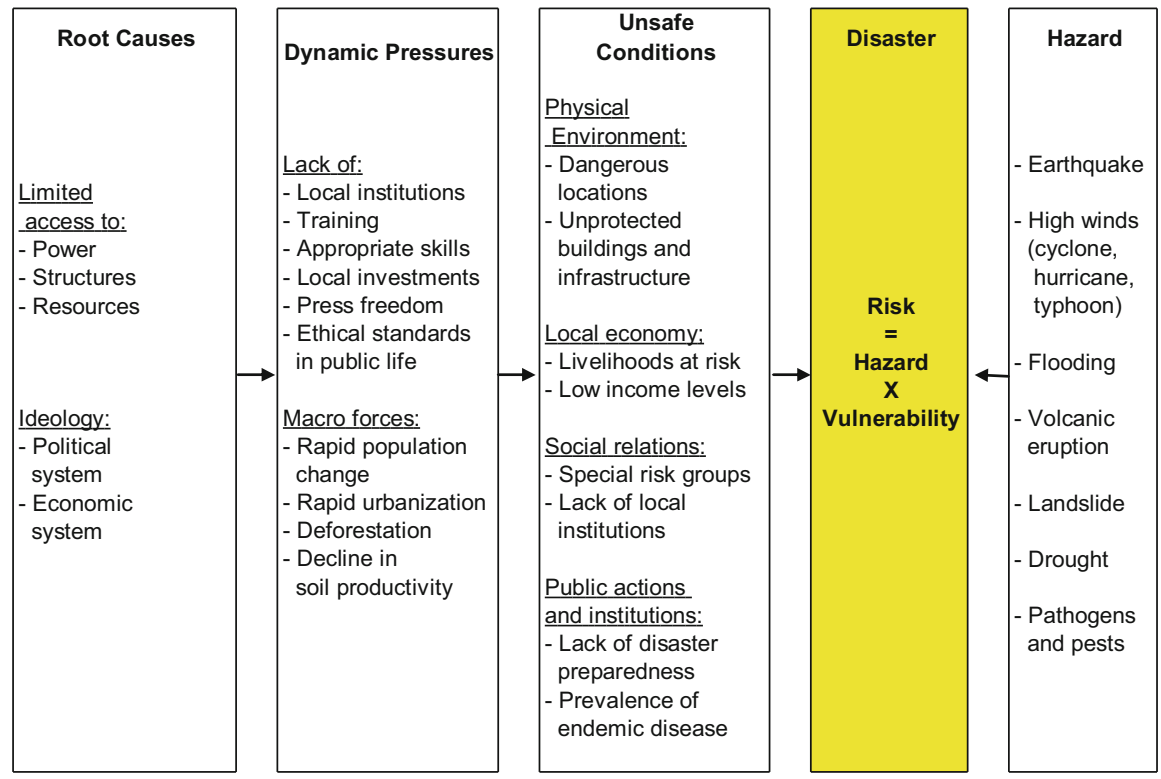

Fig. 11.2 Pressure and release model (Wisner and Blaikie 2004)

model, and for this research using a political ecology lens, examines the relationships between political and economic structures, the physical environment, and communities, to understand 'processes that generate vulnerability' (Wisner and Blaikie 2004) and explain differences in exposure, impacts and ability to cope with previous or future hazards (Eakin and Luers 2006).

The PAR Model explains disasters as the 'intersection of the natural hazard and the processes that generate vulnerability' (Wisner and Blaikie 2004; Blaikie and Brookfield 1987; Birkmann 2006). These processes, explained in part by political ecology, are categorized as root causes, dynamic pressures and unsafe conditions, as shown in Fig. 11.2, and are based on physical, political, economic and social environments and variables.

For this research, the analysis included the role of DRE systems in improving the dynamic pressures and unsafe conditions that decrease vulnerability as well as how DRE systems can be more robust in order to decrease $t$ impact of the hazards on them, and reducing the overall risk of the disaster.

\subsection{Methodology}

I assessed 15 community-owned renewable energy projects in Guatemala and Nicaragua, which were selected based on general and project type specific criteria. 
General criteria included projects:

1. Small-scale (less than $5 \mathrm{MW}$ )

2. Renewable energy (solar photovoltaic, wind energy, run of the river hydroelectric, biogas)

3. Located in a rural community

Following are the criteria for development project selection:

1. Productive-use (income-creating or enhancing) application

2. Implemented for at least 2 years and still working

3. Community owned

The criteria for climate change mitigation project selection follow:

1. A Clean Development Mechanism (CDM), a Voluntary Carbon Offset (VCO) or an Early Warning System (EWS) project

Disaster Relief projects were chosen following these criteria:

1. Developed as part of a relief or reconstruction program.

And adaptation related criteria?

I added two projects because their governance structures provided useful answers to the research questions although they did not fit the criteria of being community owned and of a productive-use application. These two separate projects consisted of individual home lighting solar photovoltaic systems; one of them a loan program implemented by a government Ministry in communities which would benefit from the national electric grid extension in the short to medium terms and one implemented by a national NGO in isolated communities that would never benefit from grid extension. Table 11.2 categorizes the case studies by country, type and renewable energy resource.

Figures 11.3 and 11.4 below show the geographical distribution of the projects. As mentioned above, in the cases where I evaluated programs, the star indicates where the cluster of projects is located.

The projects were evaluated on economic, developmental and climate change indicators, which included indicators focusing on sustainable development, poverty alleviation, emissions reductions, and climate vulnerability. I examined how the type of common property governance, local historical and environmental background and project implementation process influenced the project success in meeting multiple objectives of climate adaptation, mitigation and development. Data collection methods included participatory poverty assessment techniques, semistructured interviews, stakeholder analysis, and a combination of rapid and participatory methods. The analysis of sustainable development and vulnerability used Sustainable Livelihoods Approach methodologies and emissions reductions were calculated using carbon reduction methodologies of the IPCC.

Figures 11.5 and 11.6 portray the logical flowcharts from which the indicators for this research were derived for each of the two main research questions. Tables 11.3 and 11.4 list the specific indicators used. 
Table 11.2 Case study projects

\begin{tabular}{|c|c|c|c|c|}
\hline Country & Type & $\begin{array}{l}\text { Renewable } \\
\text { energy source }\end{array}$ & Name & Capacity \\
\hline \multirow[t]{3}{*}{ Guatemala } & \multirow[t]{3}{*}{ Development } & Hydroelectric & \multirow[t]{3}{*}{ Nueva Alianza } & $16 \mathrm{~kW}$ \\
\hline & & Biodiesel & & $48 \mathrm{gal} / 48 \mathrm{~h}$ \\
\hline & & Biogas & & N/A \\
\hline Guatemala & CDM & Hydroelectric & San Isidro & $3.92 \mathrm{MW}$ \\
\hline Guatemala & $\mathrm{VCO}$ & Hydroelectric & Chel & $165 \mathrm{~kW}$ \\
\hline Guatemala & Disaster relief & PV & $\begin{array}{l}\text { Cahabón Post-Mitch } \\
\text { reconstruction }^{\text {a }}\end{array}$ & $40 \mathrm{~W}$ \\
\hline Guatemala & Development & $\mathrm{PV}$ & $\begin{array}{l}\text { Chapín Abajo } \\
\text { women's coop }\end{array}$ & $60 \mathrm{~W}$ \\
\hline Guatemala & Development & $\mathrm{PV}$ & $\begin{array}{l}\text { Cancuén Archaeo- } \\
\text { logical site }\end{array}$ & $\begin{array}{l}105 \mathrm{~W} \text { (in } 3 \text { dif- } \\
\text { ferent locations) }\end{array}$ \\
\hline Guatemala & $\begin{array}{l}\text { Early-warning } \\
\text { systems }\end{array}$ & PV & $\begin{array}{l}\text { Early warning } \\
\text { systems }^{\mathrm{a}}\end{array}$ & $35 \mathrm{~W}$ \\
\hline Guatemala & Development & PV & $\begin{array}{l}\text { Ministry of energy } \\
\text { and mines loan }\end{array}$ & $45 \mathrm{~W} 5$ \\
\hline Guatemala & Development & $\mathrm{PV}$ & ADIM Quichéa & $12-65 \mathrm{~W}$ \\
\hline Nicaragua & Development & $\begin{array}{l}\text { PV battery } \\
\text { charging } \\
\text { station }\end{array}$ & $\begin{array}{l}\text { Francia Sirpi and } \\
\text { Awastingni }\end{array}$ & $2.4 \mathrm{~kW}$ in 3 arrays \\
\hline Nicaragua & Development & $\begin{array}{l}\text { PV water } \\
\text { pumping }\end{array}$ & El Trapiche & $600 \mathrm{~W}$ \\
\hline Nicaragua & CDM & Hydro & El Bote & $930 \mathrm{~kW}$ \\
\hline Nicaragua & $\begin{array}{l}\text { Development/in } \\
\text { process of CDM }\end{array}$ & Hydro & Río Bravo & $180 \mathrm{~kW}$ \\
\hline Nicaragua & Development & $\mathrm{PV}$ & $\begin{array}{l}\text { Solar women of } \\
\text { Totogalpa }\end{array}$ & $95 \mathrm{~W}$ \\
\hline Nicaragua & $\begin{array}{l}\text { Early warning } \\
\text { systems }\end{array}$ & $\mathrm{PV}$ & $\begin{array}{l}\text { Early warning } \\
\text { systems }^{\mathrm{a}}\end{array}$ & $35 \mathrm{~W}$ \\
\hline
\end{tabular}

${ }^{a}$ Although these are referred to as projects, these constituted programs with installations in diverse communities

Different methodologies were applied to each one of the sub-research questions as explained:

1. How well are projects meeting their goals of sustainable development, climate change mitigation and climate change adaptation?

Based on development literature, the main variables that are used to measure sustainable development include economic feasibility, social acceptance and environmental responsibility (Najam et al. 2003; Olsen 2007; Swart et al. 2003). The inspection protocol for the photovoltaic systems included the following:

1. System status and history:

(a) Previous technical inspections

(b) Previous and current failures

(c) Equipment replaced 


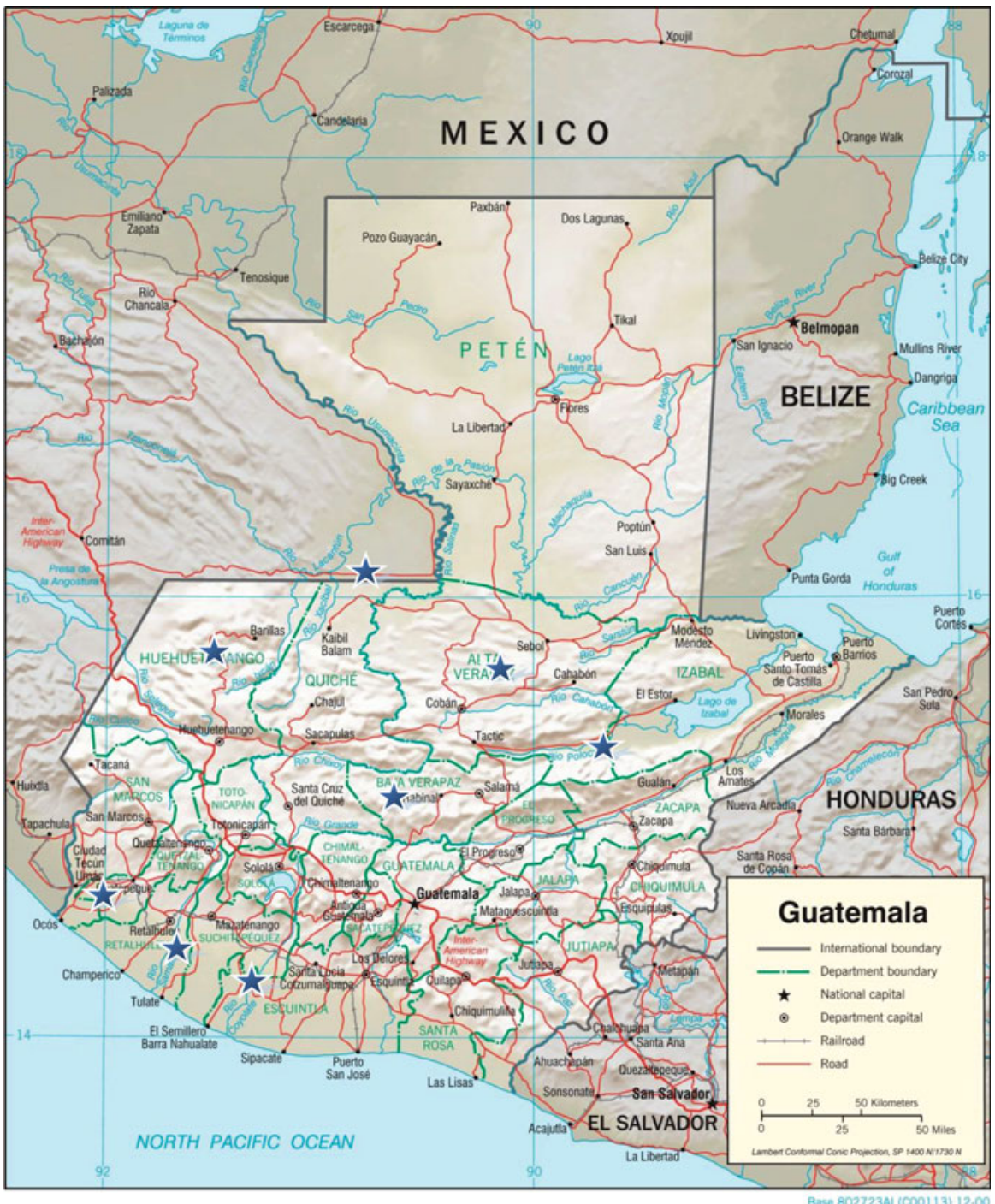

Fig. 11.3 Location of systems in Guatemala (Source: CIA World Factbook)

2. Photovoltaic array

(a) Array technical specifications

(b) Mounting structure, orientation, inclination

(c) Damaged, shaded, dirty modules

(d) Status of cables, connectors, grounding system and lightning and surge protection 


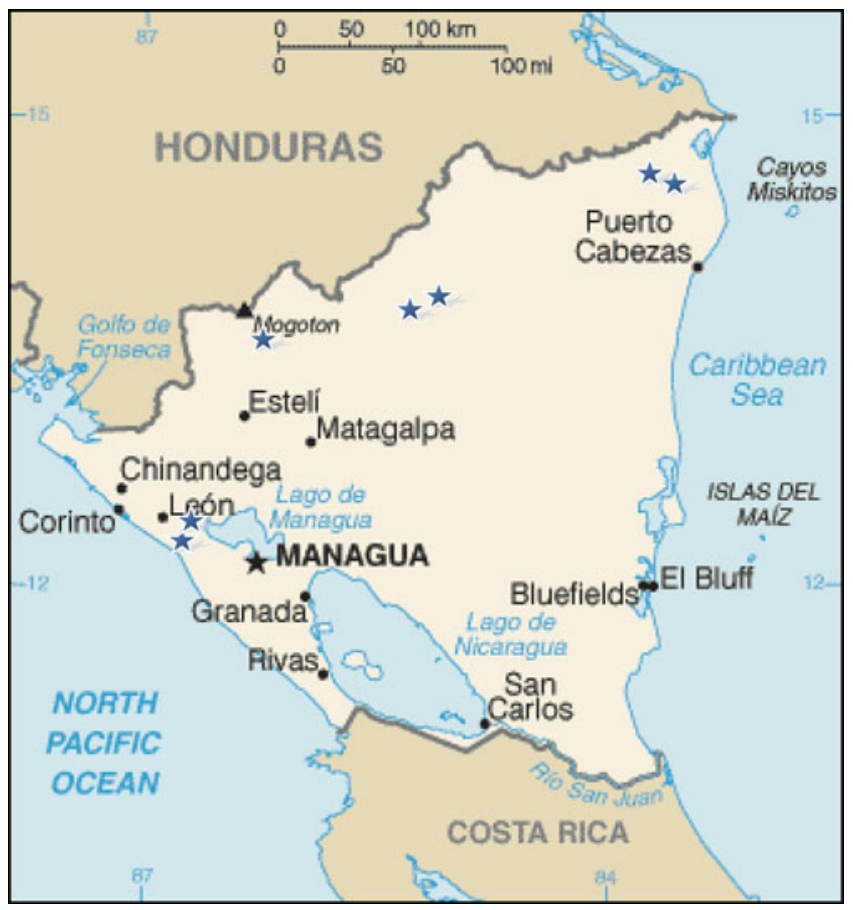

Fig. 11.4 Location of systems in Nicaragua (Source: CIA World Factbook)

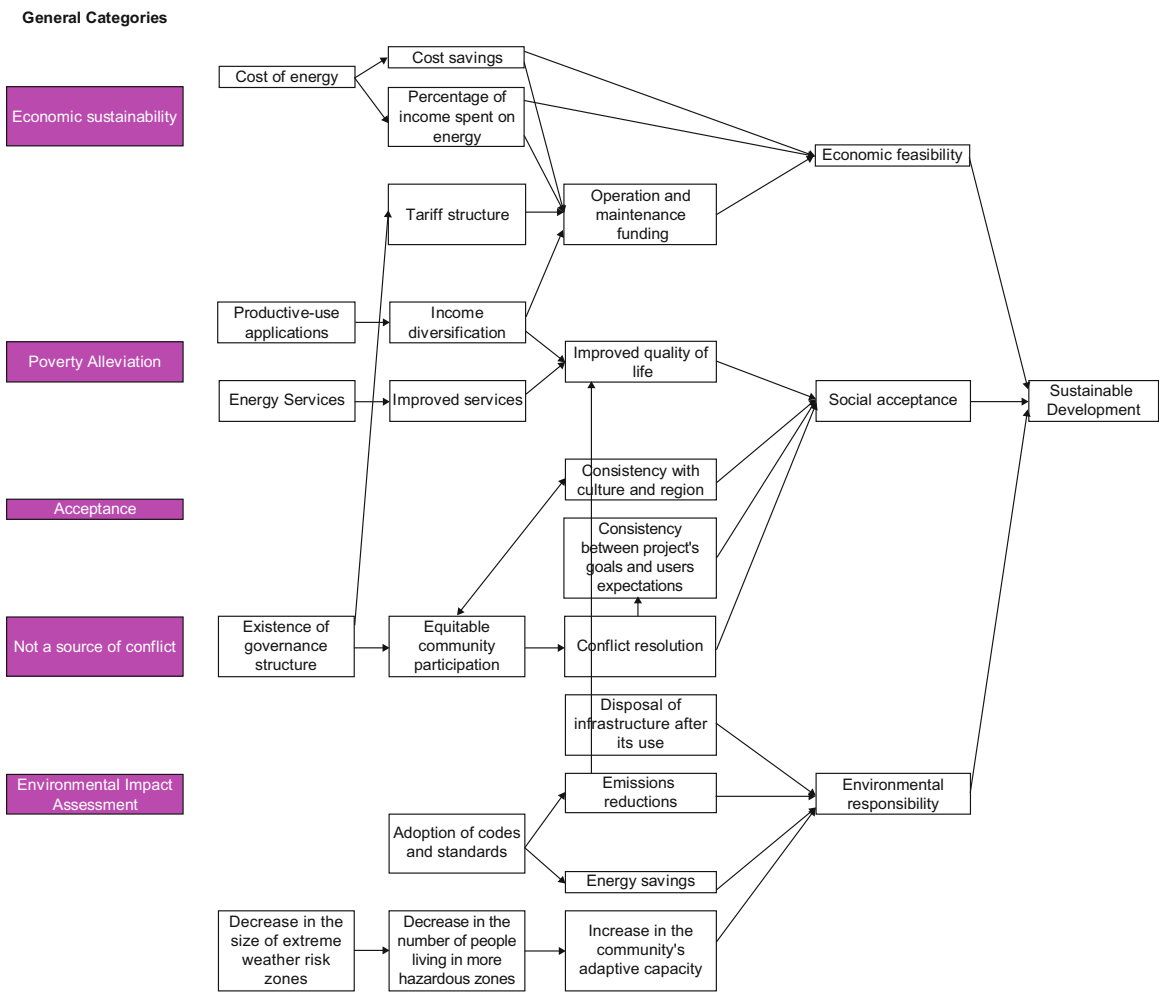

Fig. 11.5 Sustainable development indicators 


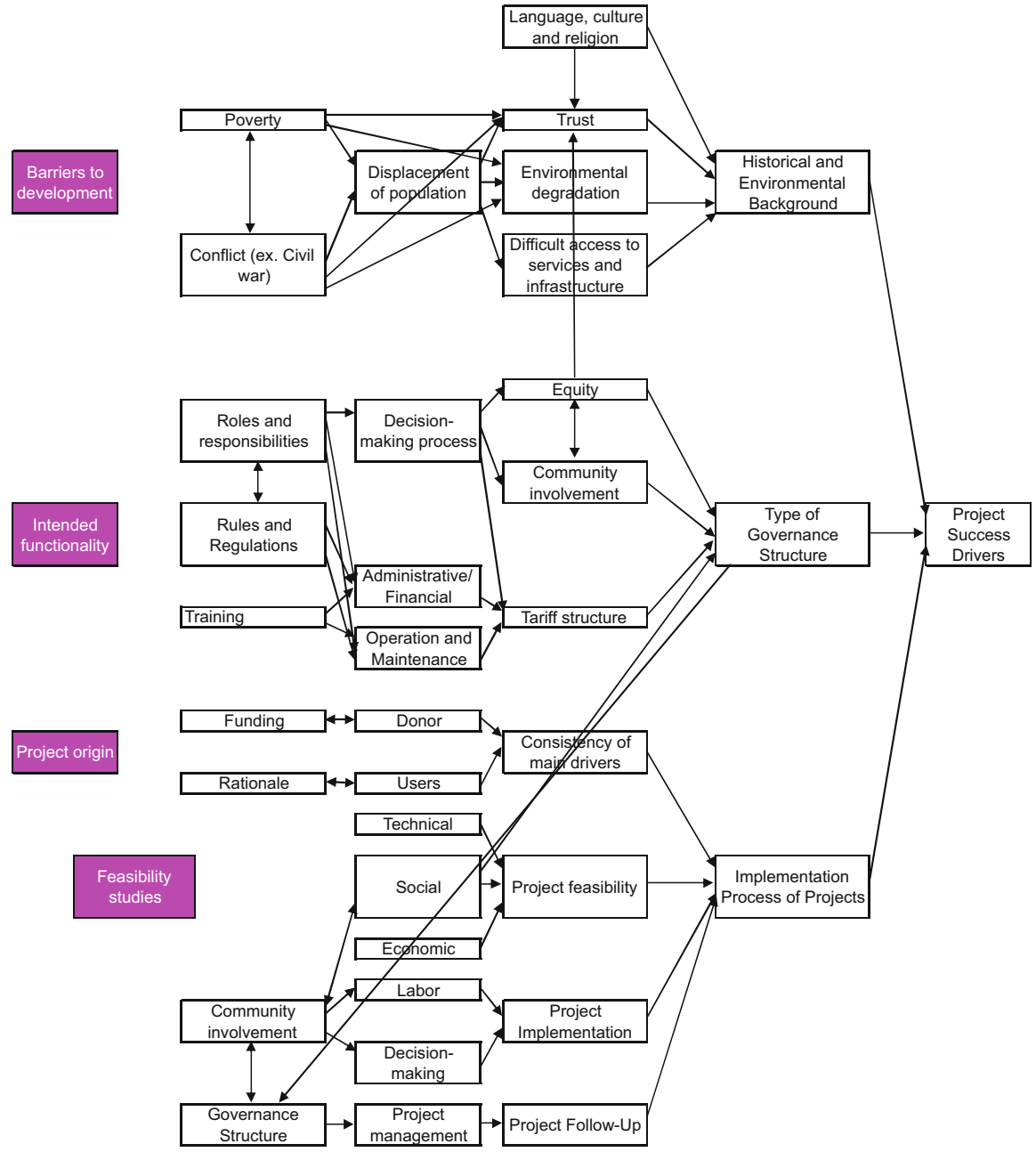

Fig. 11.6 Hypothesized project success drivers

\section{Battery bank}

(a) Bank technical specifications

(b) Battery protections

(c) Status of connectors, terminals, electrolyte level

4. Lights and other loads

(a) Technical specifications

(b) Status of electrical connections and indicators 
Table 11.3 Indicators and methodologies

\begin{tabular}{|c|c|}
\hline Indicators & Data gathering and analysis methodology \\
\hline \multicolumn{2}{|l|}{ Sustainable development: } \\
\hline $\begin{array}{l}\text { Policy objectives achieved (including National } \\
\text { Action Plans Adopted). These policy objec- } \\
\text { tives should have explicitly defined goals that } \\
\text { can be measured }\end{array}$ & $\begin{array}{l}\text { Survey question to government officials and } \\
\text { donor program managers. Official publica- } \\
\text { tions from governments and donor institutions }\end{array}$ \\
\hline $\begin{array}{l}\text { Policy objectives maintained since project } \\
\text { inception }\end{array}$ & $\begin{array}{l}\text { Survey question to government officials, } \\
\text { donor program managers, and community } \\
\text { members }\end{array}$ \\
\hline Local capacity developed: institutions & $\begin{array}{l}\text { Survey question to government officials, } \\
\text { donor program managers and community } \\
\text { members }\end{array}$ \\
\hline Local capacity developed: technical skills & $\begin{array}{l}\text { Survey question to government officials, } \\
\text { donor program managers and community } \\
\text { members }\end{array}$ \\
\hline People with increased access to energy services & $\begin{array}{l}\text { Survey question to project implementer and } \\
\text { direct observation }\end{array}$ \\
\hline $\begin{array}{l}\text { Homes adopting improved cooking/heating/ } \\
\text { lighting techniques }\end{array}$ & $\begin{array}{l}\text { Survey question to project implementer and } \\
\text { direct observation }\end{array}$ \\
\hline $\begin{array}{l}\text { Number of people with reduced exposure to } \\
\text { combustion pollutants indoors }\end{array}$ & $\begin{array}{l}\text { Survey question to project implementer and } \\
\text { direct observation }\end{array}$ \\
\hline $\begin{array}{l}\text { Number of governance structures created and } \\
\text { their functioning }\end{array}$ & $\begin{array}{l}\text { Survey question to project implementer and } \\
\text { community members. Focus groups }\end{array}$ \\
\hline $\begin{array}{l}\text { Improvement in livelihoods (natural, physical, } \\
\text { financial, social and human capitals) }\end{array}$ & $\begin{array}{l}\text { Survey questions on the five assets to com- } \\
\text { munity members. Survey questions to com- } \\
\text { munity members, and different levels of } \\
\text { government and project implementers about } \\
\text { the 'Transforming Structures and Processes' }\end{array}$ \\
\hline \multicolumn{2}{|l|}{ Poverty alleviation: } \\
\hline Reduction in the cost of energy & $\begin{array}{l}\text { Survey question to community members and } \\
\text { direct calculations }\end{array}$ \\
\hline $\begin{array}{l}\text { Reduction in the percentage of income spent on } \\
\text { energy sources }\end{array}$ & Direct calculations \\
\hline Increase in productive time & Survey question to community members \\
\hline Diversification of income sources & Survey question to community members \\
\hline $\begin{array}{l}\text { Increase in number of microenterprises } \\
\text { generated }\end{array}$ & Survey question to community members \\
\hline $\begin{array}{l}\text { Improvement in health and education } \\
\text { infrastructure }\end{array}$ & $\begin{array}{l}\text { Survey question to community members, pro- } \\
\text { ject implementers and government }\end{array}$ \\
\hline Improvement in health and education services & $\begin{array}{l}\text { Survey question to community members, pro- } \\
\text { ject implementers and government }\end{array}$ \\
\hline Formalization of land rights & $\begin{array}{l}\text { Survey question to community members, pro- } \\
\text { ject implementers and government }\end{array}$ \\
\hline \multicolumn{2}{|l|}{ Economic feasibility: } \\
\hline 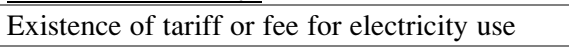 & Survey question to community members \\
\hline $\begin{array}{l}\text { Existence of a bank account or other form of } \\
\text { tariff management }\end{array}$ & Survey question to community members \\
\hline
\end{tabular}


Table 11.3 (continued)

\begin{tabular}{|c|c|}
\hline Indicators & Data gathering and analysis methodology \\
\hline $\begin{array}{l}\text { Use of the tariff or fee to cover operation and } \\
\text { maintenance }(O \& M) \text { costs (this includes pre- } \\
\text { ventive, short term and long term maintenance) }\end{array}$ & Survey question to community members \\
\hline \multicolumn{2}{|l|}{ Social acceptability: } \\
\hline Cultural and religious acceptance & Survey question to community members \\
\hline $\begin{array}{l}\text { Consistency between project goals and user } \\
\text { expectations }\end{array}$ & Survey question to community members \\
\hline $\begin{array}{l}\text { Additional benefits (for example, spending } \\
\text { more time with family) }\end{array}$ & Survey question to community members \\
\hline $\begin{array}{l}\text { Source of conflict (for example, misuse of } \\
\text { tariff) }\end{array}$ & Survey question to community members \\
\hline \multicolumn{2}{|l|}{ Environmental responsibility: } \\
\hline $\begin{array}{l}\text { Existence and implementation of an environ- } \\
\text { mental impact assessment }\end{array}$ & $\begin{array}{l}\text { Survey question to project implementers and } \\
\text { government agencies }\end{array}$ \\
\hline Consideration for disposal of used components & $\begin{array}{l}\text { Survey question to community members, pro- } \\
\text { ject implementers and government }\end{array}$ \\
\hline \multicolumn{2}{|l|}{ Emissions reductions: } \\
\hline $\begin{array}{l}\text { Increase or decrease in } \mathrm{CO} 2 \text { emissions (tons of } \\
\text { carbon) }\end{array}$ & $\begin{array}{l}\text { Simplified estimate based on IPCC } \\
\text { methodologies }\end{array}$ \\
\hline Energy savings (tons of oil equivalent) & $\begin{array}{l}\text { Simplified estimate based on IPCC } \\
\text { methodologies }\end{array}$ \\
\hline Cost savings & Calculation \\
\hline Standards adopted and implemented & $\begin{array}{l}\text { Inspection of renewable energy systems fol- } \\
\text { lowing standard protocols and survey question }\end{array}$ \\
\hline \multicolumn{2}{|l|}{ Adaptive capacity: } \\
\hline $\begin{array}{l}\text { Change in the number of people living in more } \\
\text { hazardous zones }\end{array}$ & $\begin{array}{l}\text { Direct observation, survey question to com- } \\
\text { munity members and government }\end{array}$ \\
\hline $\begin{array}{l}\text { Decrease in the size of extreme weather risk } \\
\text { zones }\end{array}$ & $\begin{array}{l}\text { Direct observation, survey question to com- } \\
\text { munity members and government }\end{array}$ \\
\hline $\begin{array}{l}\text { Increase in the community's adaptive capacity } \\
\text { (creation of social networks or increased } \\
\text { knowledge of technologies that can help cope } \\
\text { with disaster, through the use of renewable } \\
\text { energy systems) }\end{array}$ & $\begin{array}{l}\text { Direct observation, survey question to com- } \\
\text { munity members and government }\end{array}$ \\
\hline
\end{tabular}

\section{Charge controller and inverter}

(a) Number and capacity of each light and appliance

(b) Indication of functionality of each light and appliance

2. What are the relative roles of local historical background and physical characteristics, type of community governance, and funding source and project implementation process in the success of projects in meeting adaptation, mitigation and development goals?

The background of a location can give more insight into its current poverty, development and climate vulnerability status and how the project can be designed. 
Table 11.4 Indicators and methodologies

\begin{tabular}{l|l}
\hline Historical and environmental background of locations: \\
\hline Previous conflict (for example, civil war) & Literature review and survey question (to who?) \\
\hline History of extreme poverty/poverty & Literature review \\
\hline Displaced populations & Literature review \\
\hline Disenfranchisement due to language barriers & Literature review \\
\hline Governance structure: & $\begin{array}{l}\text { Focus group and survey question to community } \\
\text { members }\end{array}$ \\
\hline Type of governance structure & $\begin{array}{l}\text { Focus group and survey question to community } \\
\text { members }\end{array}$ \\
\hline $\begin{array}{l}\text { Existence of other community governance } \\
\text { structures }\end{array}$ & $\begin{array}{l}\text { Focus group and survey question to community } \\
\text { members }\end{array}$ \\
\hline Functionality and effectiveness & $\begin{array}{l}\text { Focus group and survey question to community } \\
\text { members }\end{array}$ \\
\hline Existence of internal rules and regulations \\
\hline Equitable access & $\begin{array}{l}\text { Focus group and survey question to community } \\
\text { members }\end{array}$ \\
\hline
\end{tabular}

Funding sources and implementation process of project:

\begin{tabular}{l|l}
\hline Funding sources of the project & Project implementer, project documents \\
\hline $\begin{array}{l}\text { Existence of pre-feasibility and feasibility } \\
\text { studies }\end{array}$ & Project implementer, project documents \\
\hline $\begin{array}{l}\text { Community socialization and training } \\
\text { process }\end{array}$ & Project implementer, project documents \\
\hline Existence of O\&M plan & Project implementer, project documents \\
\hline Monitoring and evaluation & Project implementer, project documents \\
\hline
\end{tabular}

For example, a background that includes previous conflict and displacement of populations can have an impact on trust, environmental degradation, and access to resources, which also shape projects and need to be considered during project planning and implementation. Environmental degradation can impact the renewable energy system design and dictate other activities that the users will need to carry out for the system to continue working properly. A common example is reforestation activities in the upper watersheds of small-scale hydro systems. The implementation process of projects is another hypothesized driver. Pre-feasibility studies must be conducted to determine if projects are technically and economically feasible, and to highlight relevant social concerns. Having proper operation and maintenance $(\mathrm{O} \& \mathrm{M})$ plans will ensure that the system will continue working and providing benefits after the donor and implementers are gone.

\subsection{Analysis}

\subsubsection{Meeting the Triple Objectives}

The results show that, under certain circumstances and design considerations, renewable energy projects can simultaneously meet these three objectives, and 
thus that responses to climate change mitigation and adaptation can be integrated with poverty alleviation and sustainable development. Small scale hydroelectric and solar systems can reduce emissions, enable adaptation and help local livelihoods although there are numerous problems that limit the success of projects including poor design, inequitable distribution of benefits, negative user perceptions, and poorly designed or non-existent governance and maintenance structures.

Although the design of some case study projects did not allow for the triple objective to be currently met, this does not preclude the projects from meeting it in the future. In some projects, a proper PAR analysis wasn't carried out as there were no extreme weather events reported or any other emergency that showed the usefulness, robustness or vulnerability of the technology or of the population thanks to the infrastructure. Indeed, some DRE projects can be more robust, and some have already been rebuilt after specific extreme weather events. Some users indicated that their systems could still be working had the local donor or implementing NGO been more aware and visited more often and not disappeared. This points to the need for greater and better monitoring as well as evaluation, which hadn't been carried out in some of the projects visited, despite their being implemented for more than 5 years.

Table 11.5 gives a summary of the results of all the case studies, according to each major category of indicators.

The notes below explain in greater detail the concept of each column.

\subsection{Renewable Energy and Climate Adaptation}

As hypothesized, DRE systems have been seen to both increase and decrease vulnerability to extreme climate events. To date, the potential response to extreme weather events of DRE systems has hardly been considered and it has been seen that they are vulnerable to extreme weather events which can harm users and hamper their stated goals such as in Nicaragua. For example, a woman in Guatemala had a nervous breakdown when her solar PV system had a short circuit inside her house during a particular storm. In this case, the fault was due to improper system installation which wasn't reported earlier as this was the first external visit to the system and household. On the other hand, one case study, Nueva Alianza, used their biodiesel system after only 1 day of being installed, and it was robust enough to withstand the force of Hurricane Stan. In general, the case studies helped identify the main vulnerabilities of DRE systems to extreme climate events. The case studies also showed that communities in which adaptation goals are being met are communities in which, more often than not, development goals are also being achieved. Actions that enable adaptation also enable development, such as communications, alternate income sources and more community unity. However, research results also indicate that in most cases, adaptation to natural disasters is better in communities where there is a good governance structure and where the renewable energy system is commonly owned. Although this result might have 


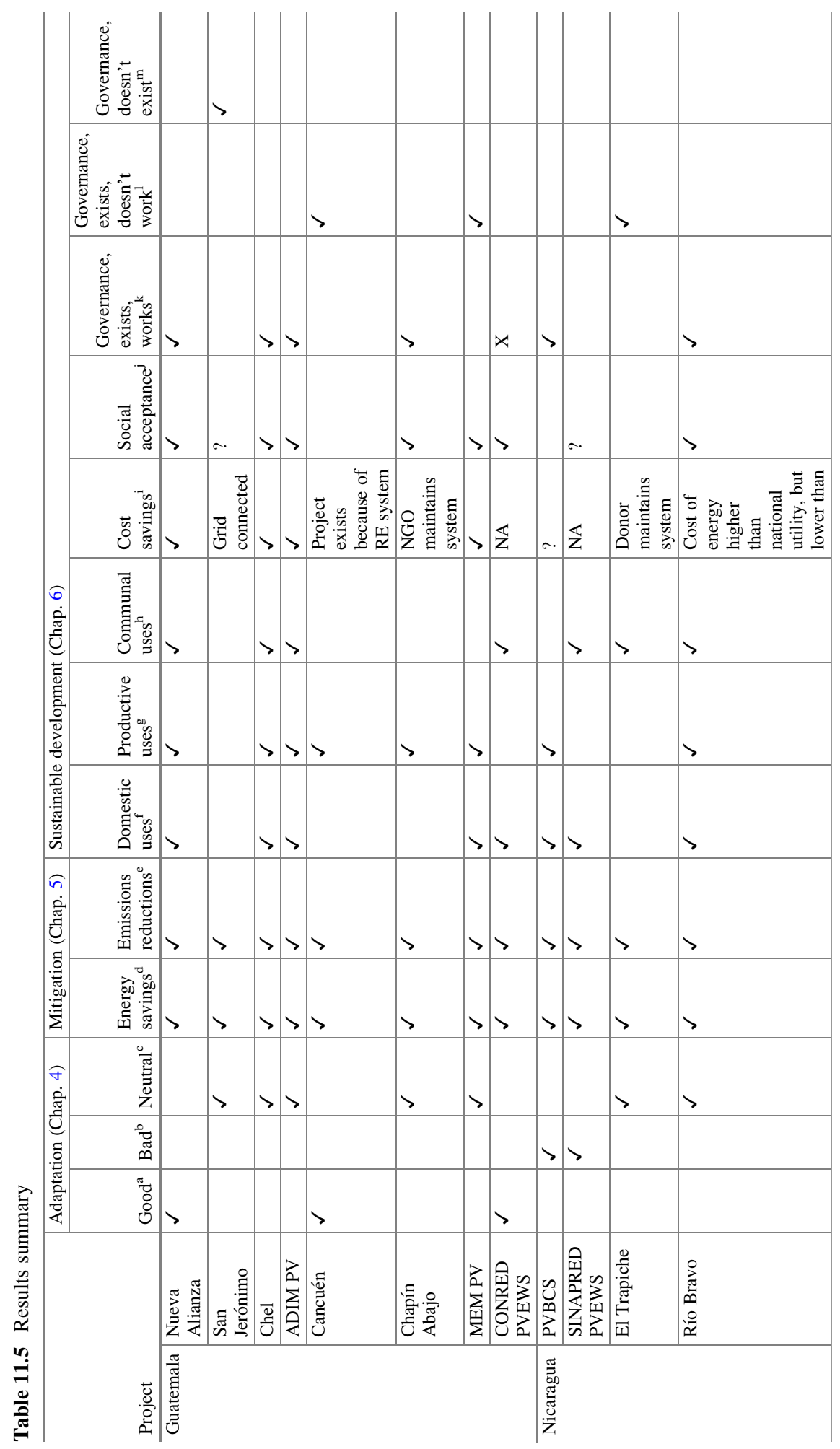




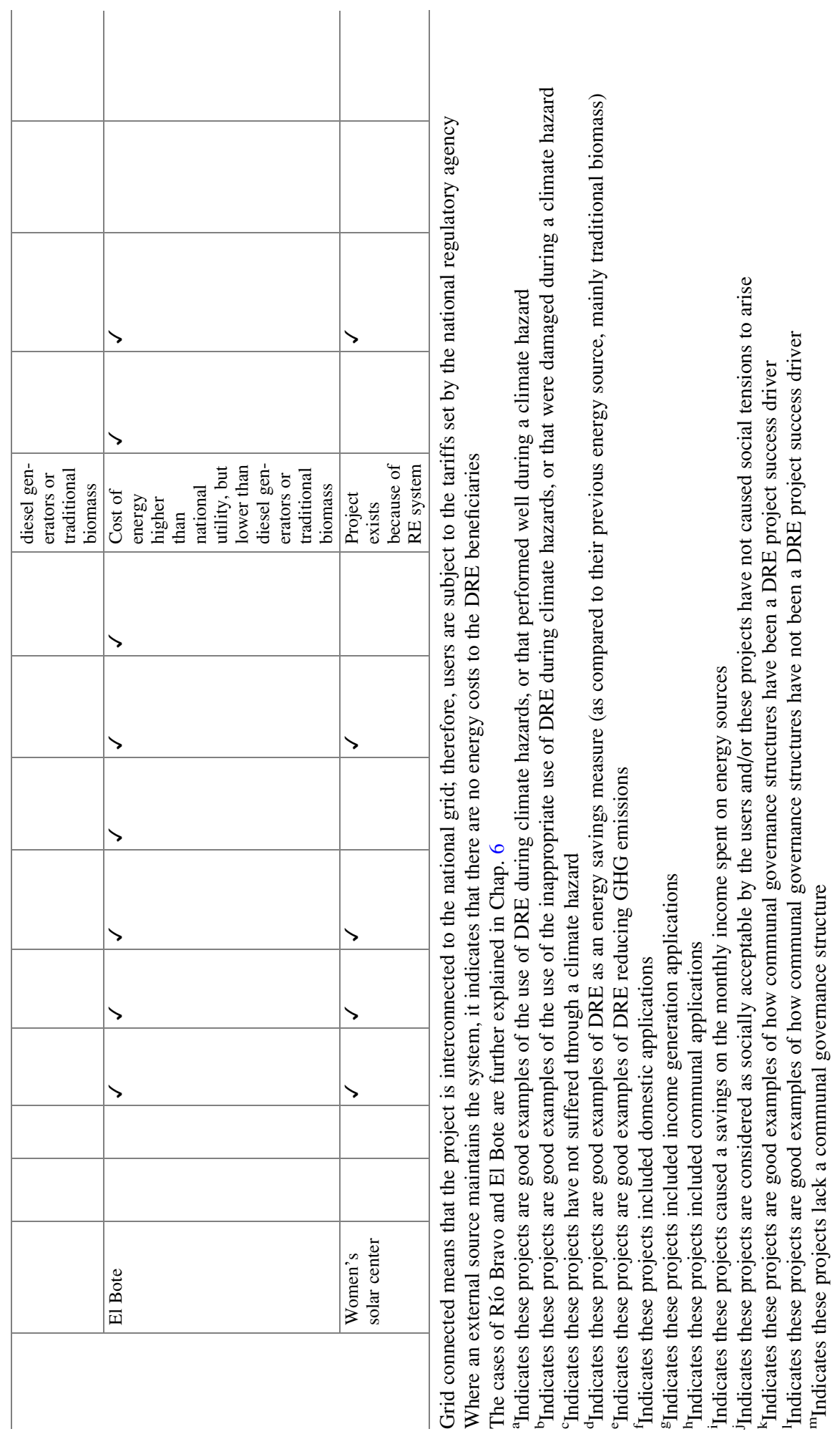


been expected, what is surprising is that technical design and standards didn't play a significant role and, contrary to expectation, the centralized nature of the infrastructure did have an impact through the respective governance structures. That is, decentralized infrastructure projects tend to have weak communal governance structures that aren't conducive to good adaptation strategies, while the opposite proved to be true. This fact highlights the important correlation between infrastructure centralization and robust governance structures, which was not originally hypothesized.

\subsection{Renewable Energy and Climate Mitigation}

Community scale DRE projects have encountered difficulties with the CDM despite them meeting emissions reductions goals. Besides the well documented barriers of a lengthy process not understood at the community level, and the high transactions costs, it is very difficult to calculate the net amount of emission reductions because of deficiencies in baseline emissions calculations. This is particularly true in projects where a subset of the beneficiaries enjoyed some kind of modern energy source, whether it was grid electricity or a diesel or gas generator. One project in Nicaragua exemplifies this as the baseline is calculated with the emissions factor of the country's energy mix, even when 18 of the 20 beneficiary communities used traditional energy sources, in which their emissions are considerably lower. Other projects highlight the finding that DRE projects can increase emissions: as electricity demand increases through the use of new appliances, use of fossil fuels tends to increase when the DRE system can not supply electricity for those new appliances. The most common cases seen were in stores that relied on refrigerators, whether through a PV system or a hydroelectric plant. In one community, their own DRE system no longer has sufficient capacity to meet the community's demand and they are now thinking of a grid connection. These results are similar to those found in India (Reddy et al. 2006), which also highlight both the needs for involvement of local communities and of vulnerability and sustainability analysis of local resource management. The latter were missing from most of the case studies analysed in this research.

Table 11.6. describes the changes in supply, infrastructure, and demand that occurred with each project. The changes in demand reflect the changes the systems were designed for.

\subsection{Renewable Energy and Sustainable Development}

DRE projects were found to have a positive impact on livelihoods assets by improving its five capitals: financial, physical, human, social, and environmental. Financial capital was enhanced by energy cost savings, productive use and alternate 
Table 11.6 Changes in energy supply, demand and infrastructure of case study projects

\begin{tabular}{|c|c|c|c|}
\hline Project & Change in supply & Change in infrastructure & Change in demand \\
\hline $\begin{array}{l}\text { Nueva a } \\
\text { Alianza }\end{array}$ & $\begin{array}{l}\text { From traditional biomass } \\
\text { to biodiesel and micro- } \\
\text { hydroelectric plant }\end{array}$ & $\begin{array}{l}\text { Construction of the com- } \\
\text { munal electricity grid and } \\
\text { installation of } \\
\text { connections }\end{array}$ & $\begin{array}{l}\text { Use of household and } \\
\text { office appliances, and } \\
\text { implementation of pro- } \\
\text { ductive use of projects }\end{array}$ \\
\hline San Isidro & $\begin{array}{l}\text { Grid-connected small- } \\
\text { scale hydroelectric plant }\end{array}$ & None & None \\
\hline Chel & $\begin{array}{l}\text { From traditional biomass } \\
\text { to micro-hydroelectric } \\
\text { plant }\end{array}$ & $\begin{array}{l}\text { Construction of a com- } \\
\text { munal electricity grid, } \\
\text { public lighting, and } \\
\text { installation of internal } \\
\text { electric home connections }\end{array}$ & $\begin{array}{l}\text { Use of household and } \\
\text { office appliances, and } \\
\text { implementation of pro- } \\
\text { ductive use projects }\end{array}$ \\
\hline Cahabón & $\begin{array}{l}\text { From traditional biomass } \\
\text { to solar PV home } \\
\text { lighting }\end{array}$ & $\begin{array}{l}\text { Internal electric home } \\
\text { installations }\end{array}$ & $\begin{array}{l}\text { Use of basic household } \\
\text { appliances ( } 2 \text { CFL's, } \\
\text { radio, cell phone charg- } \\
\text { ing, and occasionally a } \\
\text { black and white TV) }\end{array}$ \\
\hline $\begin{array}{l}\text { Chap in } \\
\text { Abajo }\end{array}$ & $\begin{array}{l}\text { The workshop had no } \\
\text { energy source prior to } \\
\text { the system (work was } \\
\text { mainly carried out during } \\
\text { daylight) }\end{array}$ & $\begin{array}{l}\text { Internal electric home } \\
\text { installations }\end{array}$ & Use of two CFL's \\
\hline Cancuén & $\begin{array}{l}\text { Ecotourism project } \\
\text { started with PV system }\end{array}$ & $\begin{array}{l}\text { Internal electric installa- } \\
\text { tions in offices and tourist } \\
\text { bungalows }\end{array}$ & $\begin{array}{l}\text { Use of radio- } \\
\text { communications, CFL's } \\
\text { and cell phone charging }\end{array}$ \\
\hline $\begin{array}{l}\text { Guatemala } \\
\text { PVEWS }\end{array}$ & $\begin{array}{l}\text { PVEWS formerly used } \\
\text { diesel generations }\end{array}$ & $\begin{array}{l}\text { Internal electric home } \\
\text { installations }\end{array}$ & $\begin{array}{l}\text { Radio-communications } \\
\text { and CFL's }\end{array}$ \\
\hline $\begin{array}{l}\text { Guatemala } \\
\text { MEM }\end{array}$ & $\begin{array}{l}\text { From traditional biomass } \\
\text { to solar PV home } \\
\text { lighting }\end{array}$ & $\begin{array}{l}\text { Internal electric home } \\
\text { installations }\end{array}$ & $\begin{array}{l}\text { Use of basic household } \\
\text { appliances ( } 2 \text { CFL's } \\
\text { radio, cell phone charg- } \\
\text { ing, and occasionally a } \\
\text { black and white TV) }\end{array}$ \\
\hline ADM & $\begin{array}{l}\text { From traditional biomass } \\
\text { to solar PV home } \\
\text { lighting }\end{array}$ & $\begin{array}{l}\text { Internal electric home } \\
\text { installations }\end{array}$ & $\begin{array}{l}\text { Use of basic household } \\
\text { appliances ( } 2 \text { CFL's, } \\
\text { radio, cell phone charg- } \\
\text { ing, and occasionally a } \\
\text { black and white TV) }\end{array}$ \\
\hline PVBCS & $\begin{array}{l}\text { From traditional biomass } \\
\text { to battery systems }\end{array}$ & $\begin{array}{l}\text { Internal electric home } \\
\text { installations }\end{array}$ & $\begin{array}{l}\text { Use of basic household } \\
\text { appliances ( } 2 \text { CFL's, } \\
\text { radio, cell phone charg- } \\
\text { ing, and occasionally a } \\
\text { black and white TV) }\end{array}$ \\
\hline $\begin{array}{l}\text { EI Trapi } \\
\text { che }\end{array}$ & $\begin{array}{l}\text { Project started with the } \\
\text { PV system }\end{array}$ & $\begin{array}{l}\text { Pumping system, piping, } \\
\text { tap }\end{array}$ & Pumping system \\
\hline EI Bote & $\begin{array}{l}\text { Micro-hydroelectric } \\
\text { plant, grid connection } \\
\text { and traditional biomass }\end{array}$ & $\begin{array}{l}\text { Construction of the com- } \\
\text { munal electricity grid, } \\
\text { public lighting, and } \\
\text { installation of internal } \\
\text { electric home connections }\end{array}$ & $\begin{array}{l}\text { For those that had tradi- } \\
\text { tional biomass, they cur- } \\
\text { rently use basic } \\
\text { household appliances } \\
\text { ( } 2 \text { CFL's, radio, cell }\end{array}$ \\
\hline
\end{tabular}


Table 11.6 (continued)

\begin{tabular}{l|l|l|l}
\hline Project & Change in supply & Change in infrastructure & Change in demand \\
\hline Rio Bravo & $\begin{array}{l}\text { From traditional biomass } \\
\text { to mini-hydroelectric } \\
\text { plant }\end{array}$ & $\begin{array}{l}\text { Construction of the com- } \\
\text { munal electricity grid, } \\
\text { public lighting, and } \\
\text { installation of internal } \\
\text { electric home connections }\end{array}$ & $\begin{array}{l}\text { phone charging, and } \\
\text { occasionally a black and } \\
\text { white TV) }\end{array}$ \\
$\begin{array}{l}\text { office appliances, and } \\
\text { implementation of pro- } \\
\text { ductive use projects }\end{array}$ \\
\hline $\begin{array}{l}\text { Women's } \\
\text { solar center }\end{array}$ & $\begin{array}{l}\text { Project started with the } \\
\text { PV system }\end{array}$ & $\begin{array}{l}\text { Internal electric installa- } \\
\text { tions in homes and the } \\
\text { solar center }\end{array}$ & $\begin{array}{l}\text { Use of basic household } \\
\text { appliances (2 CFL's, } \\
\text { radio, cell phone charg- } \\
\text { ing, and occasionally a } \\
\text { black and white TV). } \\
\text { The solar center powers } \\
\text { several computers, } \\
\text { printers and modem }\end{array}$ \\
\hline
\end{tabular}

income sources and the creation of savings mechanisms, although these were for system maintenance. Financial capital, however, was also harmed by failures in the DRE systems: during blackouts some lost refrigerated products or had to spend on fossil fuels in order to avoid losing them. Physical capital was improved by the introduction of the DRE infrastructure and other infrastructure that was enabled through the DRE projects, such as roads. Human capital saw improvements at the domestic, productive and communal levels. The DRE system enabled other services, such as better education and health, and created more unity among neighbors. Lastly, social capital was impacted through the social acceptance of the projects, especially in projects that had a strong communal participation component which, in part, lead to robust governance structures that proved to be important for the DRE projects to meet climate change adaptation goals.

\subsection{Cross Cutting Factors}

Factors including the centralized or decentralized nature of the technology or the institutions, and governance and funding entities, can enable projects to meet their stated goals, and therefore, to meet the triple objective. For the former, all projects with a centralized infrastructure, with the exception of one project, had functional governance structures. On the contrary, with the exception of one community, all communities benefited with PV systems financially managed their systems individually and the governance structures set in place ceased functions relatively soon after the installation of the systems. For the latter, the primary goals and objectives of the donor and development entities and their interaction with the communities, was key in promoting, or not, proper understanding and upkeep of the systems. This 
also leads to the conclusion that when there are multiple institutions involved in the implementation of a project, coordination among them needs to be planned from the outset. Some of the case studies presented problems because they lacked such coordination. Cultural, political, economic and social differences also play a role and can be bridged through long-term social interaction and trust building. Although this is possible and increasingly recognized, not all donor and development entities understand its importance or the need to allocate appropriate resources. Social interaction should be a two-way learning process: the community learns about the project and the means to achieve it, and the donor/developer learns about the community including its needs and background, among other information (GEF 2006).

The case studies analysed did not have a 'social funding' to help the poorest people, which still can not count on renewable energy as a modern energy option. Some projects would like to have one but presently can not afford one. Implementing one would require increasing the electricity tariff which is not possible. The lack of this 'social funding' mechanism is considered by some to increase the inequality gap. During the planning and execution phases of projects, social and economic differences among the population are not always considered, leaving the poorest population vulnerable. As Krause and Nordström also found, the high costs of renewable energy systems can also increase the inequality gap (Krause and Nordström 2004) as the poorest segment of the population remains unelectrified and unable to benefit the systems.

Technical quality was important in enabling project success. Poor technical designs and lack of appropriate operation and maintenance protocols have prevented some DRE projects from meeting stated goals: if the systems do not work as expected, people will continue to use torch pine, candles, gas lamps, or diesel gensets and will not be able to carry out the productive and social activities the electricity has enabled. As was also seen in some of the case studies, poor technical quality can also make the DRE systems, together with the users, vulnerable to extreme climate events, perhaps defeating their main purpose. In a subset of the communities, systems used very low quality components, including, for example, non-listed and non-certified PV panels that were peeling within 5 years of being installed (when their expected life ranges between 20 and 30 years) and car batteries labeled as solar deep cycle batteries.

Monitoring and evaluations are essential to meeting the triple objective, although this was very rarely carried out. Some of the projects visited could be working today had proper monitoring and evaluation taken place. Unfortunately, a number of communities where projects have failed remain without electricity and there are few prospects for further investment.

The community of Nueva Alianza provides the best example of how meeting the triple objective is possible. In the short period of time the micro hydroelectric and biodiesel projects had been installed, the community has been able to reduce their fossil fuel consumption and therefore their greenhouse gas emissions, improve the quality of life of all the families and enable their survival and that of neighboring communities in the aftermath of Hurricane Stan. This is an excellent example of 
how a renewable energy source helped this community and neighboring ones that had no communication with the 'outside world' while members of the Nueva Alianza community indicate that the rest of the world was 'out of communication with them'. The unity and strength the families already had certainly enabled the development of the DRE and productive use projects, but it can also be said that the development of these projects strengthened their bonds even more.

\subsection{Conditions, Circumstances and Considerations}

To summarize, and as analysed throughout, there are several characteristics that indicate the triple objective is possible:

1. Communities in which adaptation goals are being met are communities in which, more often than not, development goals are also being met.

2. Communities in which there is a governance structure, or some form of community participation, will be better able to cope with a natural disaster than one in which there isn't. Projects that are not communal from the outset and beginning with community participation since the planning phases will most likely not be able to meet the triple objective (GEF 2006; Reddy et al. 2006)

3 . Sound and site specific technical designs and appropriate operation and maintenance protocols that follow safety and quality codes and standards enable the triple objective.

4. Socialization needs to be considered a two-way learning process and community involvement and participation ought to happen from the beginning (GEF 2006)

5. Monitoring and evaluation are essential.

\subsubsection{Implications for Policy, Practice and/or Research}

Below I list a series of policy recommendations that can help put DRE projects on a path in which they can simultaneously achieve the triple objective, taking into consideration the cross-cutting elements necessary to success.

1. Disaster reconstruction programs are implemented in a considerably shorter period of time than development and rural electrification programs. This causes basic socialization, community participation, and training to be cut short because of timing and/or budget constraints. Recognizing that there are projects and infrastructure that need to be implemented in the short term, and that the priority is to benefit the largest number of people, the main policy recommendation is to ensure that reconstruction programs be designed to respond to future extreme climate events and other hazards to increase the community's adaptive capacity.

2. Policy makers and governments tend to relate the energy sector in general, and renewable energy projects in particular, to only climate change mitigation goals. 
In reality, as some case studies showed, the energy sector and the DRE projects are vulnerable to extreme climate events and in consequence can increase or decrease the vulnerability of the populations they serve. DRE projects are vulnerable to extreme weather events, but can also be designed to enable adaptive capacity for example through coordinated and equitable use of water in a watershed.

3. Poor technical designs and lack of appropriate operation and maintenance protocols and practices have prevented DRE projects from meeting their stated goals. This issue highlights the importance of government regulation or certification that ensures quality and safety codes and standards to avoid deceitful practices such as selling bad quality and/or pirate/fake components. Even if the systems are privately owned, there should be government controls in place and an accountability system so not 'anybody' can install systems without having the appropriate knowledge, training and licenses. Most of the Central American countries have adopted the US National Electric Code (NEC) although not all have implemented it. Donors and governments implementing DRE projects should require the compliance with such codes and standards as well as product listing. Besides requiring the use of code-compliant components and equipment, donors and governments should ensure that project installers are also licensed and certified, ensuring project sustainability and a better use of limited development budgets. Moreover, code compliance will ensure that users will not be harmed in any way, nor taken advantage of monetarily.

4. One common response received from many system users and technicians was the need for more intense and periodic training sessions to ensure systems remain functioning. Two policy recommendations are suggested:

- Set a minimum required budget for socialization and training activities as the current spending level for this topic is not sufficient to cover users' needs. Some government officials interviewed indicated the need to spend up to $10 \%$ of the total infrastructure budget on training.

- Aid program indicators tend prioritize first and foremost the number of beneficiaries or system users. Because of this, donors are reluctant to allocate additional budget towards training activities. During the interviews, some indicated this was unrealistic as there were specific goals for system beneficiaries and re-allocating budgets would mean a smaller number of systems installed which might be interpreted as inefficient use of the budget. This point has greater implications if program evaluation was carried out more periodically: when systems stop working and communities rely once again on traditional energy sources, statistics are not modified to reflect this and aid programs do not target these populations anymore as they are already considered 'electrified' or 'benefitted'. To be most effective, indicators must be both qualitative and quantitative (GEF 2005; Krause and Nordström 2004).

5. In rural indigenous populations in which other belief systems exist, such as with Mayan populations, donors and developers need an understanding of the cultural, political, economic and social differences to ensure that the appropriate 
ideas and expectations are being transmitted. In these cases, it would be appropriate for the Ministry of Culture, or its equivalent, to be involved so no rules, customs or traditions are being violated or misinterpreted.

6. Especially for hydroelectric projects of any scale, an integrated watershed management vision ought to be implemented to ensure the well-being of the entire watershed and that users of the lower watershed do not suffer negative impacts of activities carried upstream.

7. Despite the poverty alleviation goals of many DRE projects, this objective is not always achieved. In some cases, the poverty level of the beneficiaries hampers the long-term sustainability of the projects. In the case of solar PV projects, users are not always able to maintain and/or replace their batteries or other components. In the case of hydroelectric projects, the poorest families can not afford the initial connection cost. Some of the case studies showed how this can increase the inequality gap and leaves open the question if another aid program will eventually provide the service for those unserved homes. Based on this, governments might need to consider subsidizing the electricity service for the poorest segment of the population to avoid increasing inequality in rural communities. Likewise, a subsidy for social services can also be considered. As seen in the project of El Bote, rural schools can not benefit from the electricity service because the parents can afford neither the connection nor the monthly bills and the Ministry of Education rules indicate they can only cover the costs of schools located in municipalities (Krause and Nordström 2004).

8. Some case studies pointed to one key element that is often times missing from projects and which can prevent them from attaining the triple objective: monitoring and evaluation. In one of the programs evaluated, the ADIM PV project in Guatemala, I was able to see the evolution of projects of one developer over 10 years and such lessons learned do exist.

I identified five main reasons why the projects did not meet the triple objective. The first one is level of poverty as people are too poor to afford the service (in the case of the hydroelectric plants) or save for operation and maintenance (in the case of solar systems) and access to available capital becomes important, if not necessary, for system upkeep. Government schemes, such as the loan of solar systems in Guatemala, seemed to work very well, except that the poorest people cannot afford necessary battery replacement. Whether government or privately owned, an important factor is the inclusion of productive use applications that can help families gain more income that could help maintain an available cash flow. The second reason is inconsistency between users' expectations and donor's objectives. If users are not happy; it can create conflict, leading to systems neglect. The third reason is lack of community involvement: users were not satisfied mainly in those projects in which community involvement was minimal or non-existent, as in the bigger projects with funding from multilateral development entities or private sector. Based on the different conceptions of community involvement, a recommendation is to gauge with the community how they envision their role to be throughout the project. Unreliable energy is the fourth reason: with multiple or constant blackouts, the 
intended goals of the projects are not entirely met and in some cases, can cause more difficulties or pose a danger to the users. Last but not least, perceptions had a clear impact. People form perceptions about renewable energy systems and their functioning from their own and other users' experiences. Such perceptions can make them wary of using these technologies without adequate socialization and training. For example, in Nicaragua, a system with a bad design led to two trees being hit by lighting, and as a consequence, the family is afraid of using the system and has recommended against their use to others. It is also important to note here that positive experiences also enable greater use of DRE technologies. I also saw users purchasing their own system after seeing their neighbors' system or heard from some indicating they would purchase a new system if theirs failed.

\section{References}

Adger, W. N., Huq, S., Brown, K., Conway, D., \& Hulme, M. (2003). Adaptation to climate change in the developing world. Progress in Development Studies, 3(3), 179.

Architectural Energy Corporation. (1991). Maintenance and operation of stand-alone photovoltaic systems. Albuquerque: Sandia National Laboratories Photovoltaics Design Assistance Center.

Birkmann, J. (2006). Measuring vulnerability to natural hazards: Towards disaster resilient societies. Tokyo: United Nations University.

Blaikie, P. M., \& Brookfield, H. C. (1987). Land degradation and society. London: Methuen.

Bradshaw, B., Dolan, H., \& Smit, B. (2004). Farm-level adaptation to climatic variability and change: Crop diversification in the Canadian prairies. Climatic Change, 67(1), 119-141.

CEPAL. (2007a). La Energia y las Metas del Milenio en Guatemala, Honduras y Nicaragua. Mexico: CEPAL.

CEPAL. (2007b). Istmo Centroamericano: Estadísticas del subsector eléctrico (Datos actualizados a 2006). Mexico: CEPAL.

Crichton, D. (2007). What can cities do to increase resilience? Philosophical Transactions of the Royal Society A: Mathematical, Physical and Engineering Sciences, 365(1860), 2731-2739.

Downing, T. E., \& Patwardhan, A. (2005). UN adaptation policy frameworks for climate change: Developing strategies, policies and measures (Technical Paper 3. Assessing Vulnerability for Climate Adaptation, pp. 93-115). Cambridge: Cambridge University Press.

Eakin, H., \& Luers, A. L. (2006). Assessing the vulnerability of social-environmental systems. Annual Review of Environment and Resources, 36, 365-394. doi:10.1146/annurev.energy.30. 050504.144352

Eriksen, S., \& O'Brien, K. (2007). Vulnerability, poverty and the need for sustainable adaptation measures. Climate Policy, 7(4), 337-352.

GEF. (2005). OPS 3: Progressing toward environmental results. Third overall performance study of the GEF. Washington, DC: Global Environment Facility and ICF Consulting.

GEF. (2006). The role of local benefits in global environmental programs (Evaluation report no. 30). Washington, DC: Global Environment Facility Evaluation Office.

Great Britain. Department for International Development. (2000). Sustainable livelihoods guidance sheets. London: Dfid.

Great Britain. Department for International Development. (2004). Climate change and poverty. London: Department for International Development.

GVEP (2008). Available: www.gvep.org

Inversin, A. R. (1999 [1986]). Micro-hydropower sourcebook: A practical guide to design and implementation in developing countries. Arlington: NRECA International Foundation.

Johnson, C., Penning-Rowsell, E., \& Parker, D. (2007). Natural and imposed injustices: The challenges in implementing 'fair' flood risk management policy in England. Geographical Journal, 173(4), 374-390. 
Krause, M., \& Nordström, S. (2004). Solar photovoltaics in Africa: Experiences with financing and delivery models (Monitoring \& evaluation report series issue 2). New York: UNDP-GEF.

Linnerooth-Bayer, J., \& Mechler, R. (2006). Insurance for assisting adaptation to climate change in developing countries: A proposed strategy. Climate Policy, 6(6), 621-636.

Mills, E. (2007). Synergisms between climate change mitigation and adaptation: An insurance perspective. Mitigation and Adaptation Strategies for Global Change, 12(5), 809-842.

Moser, S.C., Kasperson, R.E., Yohe, G., \& Agyeman, J. (2007). Adaptation to climate change in the Northeast United States: Opportunities, processes, constraints. Mitigation and Adaptation Strategies for Global Change, 1-17.

Najam, A., Rahman, A. A., Huq, S., \& Sokona, Y. (2003). Integrating sustainable development into the Fourth Assessment Report of the Intergovernmental Panel on Climate Change. Climate Policy, 3(Suppl 1), S9-S17.

Naylor, R. L., Battisti, D. S., Vimont, D. J., Falcon, W. P., \& Burke, M. B. (2007). Assessing risks of climate variability and climate change for Indonesian rice agriculture. Proceedings of the National Academy of Sciences of the United States of America, 104(19), 7752-7757.

Olsen, K. H. (2007). The clean development mechanism's contribution to sustainable development: A review of the literature. Climatic Change, 84(1), 59-73.

Ostrom, E. (2002). The drama of the commons, National Research Council. Committee on the Human Dimensions of Global Change. Washington, DC: National Academy Press.

Reddy, V. R., Uitto, J. I., Frans, D. R., \& Matin. (2006). Achieving global environmental benefits through local development of clean energy? The case of Small Hilly Hydel in India. Energy Policy, 34(2006), 4069-4080.

Risser, V., \& Post, H. (1991, November). Stand-alone photovoltaic systems: A handbook of recommended design practices (SAND87-7023). Sandia PV Design Assistance Center.

Romilly, P. (2007). Business and climate change risk: A regional time series analysis. Journal of International Business Studies, 38(3), 474-480.

Sperling, F. (2003). Poverty and climate change: Reducing the vulnerability of the poor through adaptation. Washington, DC: World Bank.

Swart, R., Robinson, J., \& Cohen, S. (2003). Climate change and sustainable development: Expanding the options. Climate Policy, 3(Supplement 1), S19-S40.

Thomas, D. S. G., \& Twyman, C. (2005). Equity and justice in climate change adaptation amongst natural-resource-dependent societies. Global Environmental Change Part A, 15(2), 115-124.

Tol, R. S. J., Van der Grijp, N., Olsthoorn, A. A., \& Van der Werff, P. E. (2003). Adapting to climate: A case study on riverine flood risks in The Netherlands. Risk Analysis, 23(3), 575-583.

UNDP. (2007). Human Development Report 2007/2008. Fighting climate change: Human solidarity in a divided world. New York: Palgrave Macmillan.

Venema, H. D., \& Rehman, I. H. (2007). Decentralized renewable energy and the climate change mitigation-adaptation nexus. Mitigation and Adaptation Strategies for Global Change, 12(5), 875-900.

Wisner, B., \& Blaikie, P.M.. (2004). At risk: Natural hazards, people's vulnerability and disasters (2nd ed.). London: Routledge.

Open Access This chapter is distributed under the terms of the Creative Commons AttributionNonCommercial 4.0 International License (http://creativecommons.org/licenses/by-nc/4.0/), which permits any noncommercial use, duplication, adaptation, distribution and reproduction in any medium or format, as long as you give appropriate credit to the original author(s) and the source, provide a link to the Creative Commons license and indicate if changes were made.

The images or other third party material in this chapter are included in the work's Creative Commons license, unless indicated otherwise in the credit line; if such material is not included in the work's Creative Commons license and the respective action is not permitted by statutory regulation, users will need to obtain permission from the license holder to duplicate, adapt or reproduce the material. 